Pobrane z czasopisma Annales H - Oeconomia http://oeconomia.annales.umcs.pl Data: 26/04/2023 11:50:08

DOI:10.17951/h.2018.52.4.103-112

\begin{tabular}{lc}
\hline \multicolumn{3}{c}{ A N N A L E S } \\
UNIVERSITATIS MARIAE CURIE-SKŁODOWSKA \\
LUBLIN - POLONIA \\
VOL. LII, 4 \\
SECTIOH
\end{tabular}

Maria Curie-Skłodowska University in Lublin

\author{
WACŁAWA STARZYŃSKA
}

ORCID ID: https://orcid.org/0000-0002-7533-1790

waclawa.starzynska@poczta.umcs.lublin.pl

\title{
The Public Procurement and Innovativeness of Economy. The Perspective of Buying Agencies in Poland
}

Zamówienia publiczne a innowacyjność gospodarki - perspektywa zamawiających

Keywords: public procurement; innovations; impact of public procurement; public agencies survey

Słowa kluczowe: zamówienia publiczne; innowacyjność ofert; wpływ zamówień; preferencje zamawiających

JEL code: H40; H41; H57

\section{Introduction}

Public procurement policy, under alternative auction procedures, is an important instrument of innovation in production and cost reducing efforts [Rolfstam, 2015]. While observing the rules dealing with public procurements is possible, it is rather difficult to describe how they are applied in practice. Until January 1995, Poland lacked uniform rules or procedures for purchases made by the state and local public administration.

Introducing the Act of Public Procurement or any new law was characterized by many difficulties and much emotion. The biggest problems of implementing its rules resulted from their novelty and difficulties in overcoming old habits. Some changes in the act have taken place that can make it a system that will be compatible with the public procurement provisions of the General Agreement on Trade and Tariffs and the public procurement directives of the European Union. 
The goal of implementing the law is to establish a sound, efficient public procurement system that lays the foundations for a system that will not allow unfair competition, will protect against corruption and will be clear for all taxpayers and accepted by the procuring entity, the supplier and the contractor.

Poland joined the EU in 2004 and then introduced the Public Procurement Law, which has been changed many times since 2005 . The most important regulations were introduced in 2016 by the Amendment of Public Procurement Law, which resulted from European directives in the area of public procurement (2014/24/EU and 2014/25/EU). The positive results of these changes are that they simplify public procurement procedures, increase a role of information tools, and promote alternative targets and complementary policies by means of public procurement.

For Europe, public procurement of innovation is a central tool in the general ambition to promote demand-side politics to boost innovation and sustain competitive advantage in a global economy. Throughout the years, this interest has been evaluated by almost the whole world [OECD, 2011; UNOPS, 2014], although national governments might vary in terms of the amount of their efforts.

This paper presents the possibilities for applying and monitoring public procurement as an innovation policy tool. There are not many studies in this area. The paper discusses the pro-innovative conditions of the Polish public procurement system from the perspective of buying agencies. Data come from a survey of 100 awarding entities in the public sector. The so-called "bottom-up" approach to procurement refers to the process of gathering national data on expenditure directly from national institutions and agencies responsible for procurement. Other sources are annual reports of the Office of Public Procurement in Warsaw.

\section{General view of the public procurement market in Poland}

The Office of Public Procurement does not maintain a database about the procurement market. However, in the annual reports of this institution, there is some aggregated information that could be useful for analysis. In every annual report, we can find data about the size and structure of the number and volume of public contracts by characteristic: type, award procedure, model of award criteria, number of offers per one contract, etc.

The total number of contracting entities subject to the rules of procurement regulations ranges between 13,000 and 18,000 (it depends on public funds coming from the EU financial support). The annual procurement volume of the Polish public sector in 2010 was estimated at PLN 167 billion. In 2016, this value reached PLN 107 billion only, which equates to about $12 \%$ and $8 \%$ of the gross domestic product, respectively. The main statistical data on public procurement in Poland in recent years are presented in Tables 1-4. 
Pobrane z czasopisma Annales H - Oeconomia http://oeconomia.annales.umcs.pl

Data: 26/04/2023 11:50:08

THE PUBLIC PROCUREMENT AND INNOVATIVENESS OF ECONOMY...

Table 1. Descriptive statistics of public procurement (PP) market in Poland in 2010-2016

\begin{tabular}{|l|r|r|r|r|r|r|r|}
\hline \multicolumn{1}{|c|}{ Descriptive measures } & \multicolumn{1}{c|}{2010} & \multicolumn{1}{c|}{2011} & \multicolumn{1}{c|}{2012} & \multicolumn{1}{c|}{2013} & \multicolumn{1}{c|}{2014} & \multicolumn{1}{c|}{2015} & \multicolumn{1}{c|}{2016} \\
\hline Volume of PP (in PLN bln) & 167.0 & 144.1 & 132.7 & 143.2 & 133.2 & 116.3 & 107.4 \\
\hline Dynamics (previous year=100) & 131.8 & 86.3 & 92.1 & 107.9 & 93.0 & 87.3 & 92.3 \\
\hline Number of contracts & 195,555 & 186,232 & 188,478 & 210,302 & 174,740 & 142,262 & 129,776 \\
\hline Dynamics (previous year=100) & 102.7 & 95.2 & 101.2 & 111.6 & 83.0 & 81.4 & 91.2 \\
\hline $\begin{array}{l}\text { Average volume per one PP } \\
\text { (in PLN ths.) }\end{array}$ & 854.0 & 773.8 & 704.1 & 680.9 & 762.3 & 817.5 & 827.6 \\
\hline
\end{tabular}

Source: Author's own elaboration based on information from the Office of Public Procurement.

Table 2. Structure of PP volume by type of contracts in 2010-2016 (in \%)

\begin{tabular}{|l|c|c|c|c|c|c|c|}
\hline \multicolumn{1}{|c|}{ Type of contract } & 2010 & 2011 & 2012 & 2013 & 2014 & 2015 & 2016 \\
\hline Construction works & 43 & 39 & 45 & 38 & 40 & 33 & 34 \\
\hline Goods & 20 & 28 & 27 & 30 & 31 & 35 & 36 \\
\hline Services & 37 & 33 & 28 & 32 & 29 & 32 & 30 \\
\hline
\end{tabular}

Source: The Office of Public Procurement, Warsaw.

Table 3. Average number of bidders per one award in Poland in 2010-2016

\begin{tabular}{|l|c|c|c|c|c|c|c|c|}
\hline $\begin{array}{c}\text { Type of } \\
\text { contract }\end{array}$ & $\begin{array}{c}\text { Volume of } \\
\text { contract }\end{array}$ & 2010 & 2011 & 2012 & 2013 & 2014 & 2015 & 2016 \\
\hline \multirow{2}{*}{$\begin{array}{l}\text { Construction } \\
\text { works }\end{array}$} & BZP & 3.76 & 3.88 & 4.70 & 4.36 & 3.90 & 4.30 & 4.32 \\
\cline { 2 - 10 } & TED & 5.63 & 5.09 & 6.06 & 5.09 & 4.51 & 4.94 & n.a. \\
\hline \multirow{2}{*}{ Goods } & BZP & 2.45 & 2.39 & 2.47 & 2.48 & 2.44 & 2.35 & 2.34 \\
\cline { 2 - 10 } & TED & 2.30 & 2.25 & 2.17 & 2.33 & 2.67 & 2.34 & n.a. \\
\hline \multirow{2}{*}{ Services } & BZP & 2.57 & 2.65 & 2.79 & 2.95 & 2.99 & 2.96 & 2.80 \\
\cline { 2 - 10 } & TED & 2.94 & 2.92 & 2.68 & 2.33 & 2.39 & 3.81 & n.a. \\
\hline
\end{tabular}

BZP - value of contracts less than the EU thresholds; TED - value of contracts equal or higher than EU thresholds; n.a. - not available

Source: The Office of Public Procurement, Warsaw.

Table 4. Structure of the public procurements (PP) by award procedure in 2013-2016 (in \%)

\begin{tabular}{|l|r|r|r|r|r|r|r|c|}
\hline \multirow{2}{*}{ Award procedure } & \multicolumn{4}{|c|}{ Number of PP } & \multicolumn{5}{c|}{ Volume of PP } \\
\cline { 2 - 10 } & 2013 & 2014 & 2015 & 2016 & 2013 & 2014 & \multicolumn{1}{c|}{2015} & 2016 \\
\hline Open tender & 81.00 & 82.19 & 83.39 & 81.80 & 80.42 & 75.75 & 75.21 & 78.71 \\
\hline Two-stage tender & 0.56 & 0.74 & 0.83 & 0.70 & 5.52 & 8.11 & 13.40 & 10.64 \\
\hline Restricted bids & 18.44 & 17.07 & 15.88 & 17.50 & 14.04 & 16.14 & 11.39 & 10.65 \\
\hline
\end{tabular}

Source: Author's own elaboration on the basis of annual reports of the Office of Public Procurement, Warsaw.

The structure of contract volume is changing over time. The percentage of construction work is slowly decreasing, from $43 \%$ in 2010 , and $45 \%$ in 2012 , to $34 \%$ in 2016, while the share of goods significantly rose (from $20 \%$ in 2010 to $36 \%$ in 2016). The role of services is estimated at about one-third of all volume of public procurement in Poland.

Special attention is paid to the award procedure, which depends on the value of contracts. From the data in Table 4, we can conclude that the structure of volume differs significantly from the structure of the number of public contracts in the time period of 2013-2016. The share of procedures characterized by restricted bids, 
which are less competitive than tenders, is slowly decreasing in terms of volume of contracts and is almost stable as far as the number of public procurements goes. In recent three years, it accounts about $17 \%$.

\section{Theoretical approach to the public procurement of innovation (PPI)}

The starting point in the analysis of innovations, i.e. new combinations, is manifested as the introduction of a new good, a new method of production, the opening up of a new market or the use of a new source of supply of raw materials or new ways of organizing industries [Schumpeter, 1934].

One possibility is to define innovation in relationship to the local context, i.e. with reference to the Oslo manual, and thus to distinguish between innovations that are new to the firm, not new to the firm, new to the public authority and not new to the public authority [Appelt, Galindo-Rueda, 2014]. Studying public innovation in general, Kattel et al. [2013] point out that public innovation might not follow the same evolutionary mechanisms as private firms would.

Indicators used by the Innovation Union Scoreboard fall into three broad categories: enablers, firm activities and outputs [Adam, 2014]. Indicators of enablers concern human resources, e.g. the number of doctorate graduates in relationship to the whole population, or other measures of educational levels. Other indicators rely on publication performance and, e.g. R\&D expenditure.

Trochim, writing about evaluation policy, defines the notion of substantive policy as those policies that "get translated into operational objects and practices" [Trochim, 2009, p. 15]. One such substantive policy for public procurement of innovation are the Millennium Goals that were set for the EU to increase its R\&D investments from 1.9\% of EU GDP in 2000 to 3\% of EU GDP in 2010, to become the most competitive and dynamic knowledge-based economy in the world. A few years later, the connection to public procurement was made explicit because public procurement could provide the necessary demand for R\&D and innovation [Rolfstam, 2009]. Trochim [2009] then turns to the programs, "operational objects and practices" emerging from the substantive policies. For public procurement of innovation, there are quite a few such examples, for instance, the Lead Market Initiative or the development of pre-commercial procurement (PCP). For the Lead Market Initiative, public procurement of innovation was given a central role, emphasizing the importance of "mobilizing public authorities to act as 'launching customers' by promoting the use of public procurement practices supportive for innovation [...]" [European Commission, 2007]. Pre-commercial procurement was introduced as an "approach to procuring R\&D services", aiming specifically to bridge the gap between scientific knowledge and the market through application of public demand-pull.

Notably, the literature offers examples of attempts that could be considered judgements of to what extent the substantive policies underscore the use of public 
procurement of innovation. More recent quantitative studies have compared different innovation effects, suggesting that public procurement and university spill-overs are more important than other measures such as regulation and public funding of innovation projects [Aschhoff, Sofka, 2009].

One approach to measuring public procurement of innovation policy that is understood as operational objects, practices and programs is to benchmark the level of national implementation of concrete programs as responses to EU policy. For instance, based on a survey distributed to national representatives from the EU Member States and Associated Countries, the European Commission aimed to benchmark the extent to which pre-commercial procurement was implemented. One of the outcomes was a display in which countries were grouped into four categories: awareness raising/exploring possibilities, working on framework, framework identified and pilots started. Drawing mainly on secondary data, Izsak and Edler [2011] conduct a similar exercise addressing the implementation of demand-side policies. Also, countries are grouped into categories depending on their relative performance in terms of policy implementation. These categories are "strong policy discourse and experience", "relevant policy discourse and experimentation" and "limited policy discourse and/or action". The corroborative evidence for putting Denmark into the front-runner category - strong policy discourse and experience - is its implementation of public-private partnerships. This is indeed a very established set-up in the Danish context, but it is characterized in particular by its lack of demand aggregation, because these projects, to large extents, involve learning and pre-commercial testing of supplier-side innovation and typically do not lead to a commercial procurement [Rolfstam, Petersen, 2014].

\section{Public procurement and innovation: evidence from public entities}

In 2009-2011, a team of researchers at the University of Łódź conducted in Poland a questionnaire survey involving a sample of 100 public entities and 685 suppliers or prospective contractors [Starzyńska, Wiktorowicz, 2012]. The main purpose of the survey was to find fact-based answers to questions about public procurements of innovation and their potentially pro-innovative effects on the economy.

Empirical data from a survey of public purchasing agencies were analysed to answer the question of whether public procurements are a suitable instrument to promote demand-driven innovation. Observing the structure of the sample, it is worth mentioning that more than half of all entities were central and regional governments, about $20 \%$ were healthcare institutions and one-quarter were other entities.

A little surprisingly, only $7 \%$ of all procurement offices surveyed stated that they in the past three years had procured innovation:

- 18 contracts for services of total volume of PLN 35 billion,

- 30 contracts for construction works of total volume of PLN 50 billion, and

- 72 contracts for goods of volume of PLN 51 billion. 
Innovativeness manifested as the introduction of new goods, new methods of production and new ways of industrial organization.

Investigations consider two aspects of the characteristics of public procurement entities that may encourage public procurement of innovation:

1. Propensity of procurer to define specifications involving innovation of the goods and services; and

2. General capabilities of public client to manage public procurement of innovation, which is connected with the potential of the entity.

To answer the question of which groups of public purchasing agencies in Poland are willing to stress innovativeness of the product buying subject of PP under procedure of its describing from one side, and taking into account the potential of entity from other side, Table 5 presents the data to be analysed.

Table 5. Propensity to proceed with PPI and chosen characteristics of public procurers

(V-Cramer's coefficient)

\begin{tabular}{|c|c|c|c|c|c|c|}
\hline \multirow{2}{*}{ Characteristics of procurers } & \multicolumn{2}{|c|}{$\begin{array}{l}\text { V-Cramer's } \\
\text { coefficient }\end{array}$} & \multicolumn{2}{|c|}{ p-value } & \multicolumn{2}{|c|}{$\begin{array}{l}\text { Statistical } \\
\text { significance }\end{array}$} \\
\hline & (1) & $(2)$ & (1) & $(2)$ & (1) & $(2)$ \\
\hline Number of persons dealing with PP & 0.415 & - & 0.001 & - & yes & no \\
\hline Experience of public sector entity in PP & - & 0.384 & - & 0.003 & no & yes \\
\hline Type of public sector entity & - & - & - & - & no & no \\
\hline Annual number of PP & 0.329 & 0.443 & 0.017 & 0.001 & yes & yes \\
\hline Annual value of PP & 0.333 & 0.564 & 0.013 & 0.000 & yes & yes \\
\hline $\begin{array}{l}\text { Presence of firms with foreign capital among } \\
\text { bidders }\end{array}$ & 0.338 & - & 0.007 & - & yes & no \\
\hline
\end{tabular}

(1) - propensity to describe the innovative product in PP specification;

(2) - propensity for innovativeness resulting from the PP potential of a given entity.

Source: Author's own elaboration based on Starzyńska [2012, p. 184].

Table 6. Innovative aspect of PP product as a criterion among evaluation criteria in purchase order specification and characteristics of procurers (V-Cramer's coefficient)

\begin{tabular}{|l|c|c|c|}
\hline \multicolumn{1}{|c|}{ Characteristics of procurers } & $\begin{array}{c}\text { V-Cramer's } \\
\text { coefficient }\end{array}$ & p-value & $\begin{array}{c}\text { Statistical } \\
\text { significance }\end{array}$ \\
\hline Number of persons dealing with PP & $\mathbf{0 . 3 3 6}$ & $\mathbf{0 . 0 7 7}$ & yes \\
\hline Experience of public sector entity in PP & 0.414 & 0.108 & no \\
\hline Type of public sector entity & $\mathbf{0 . 3 9 0}$ & $\mathbf{0 . 0 2 5}$ & yes \\
\hline Annual number of PP & $\mathbf{0 . 3 5 5}$ & $\mathbf{0 . 0 5 1}$ & no \\
\hline Annual value of PP & - & - & no \\
\hline $\begin{array}{l}\text { Presence of firms with foreign capital } \\
\text { among bidders }\end{array}$ & - & - & \\
\hline
\end{tabular}

Source: Author's own elaboration based on Starzyńska [2012, p. 185].

The most important role is played by size of agency measured by the number of people dealing with PP $(\mathrm{V}=0.415)$ and their experience in PP (0.384). Scale and size of public entity demand are also significant factors facilitating process- 
es that may lead to creating markets of innovative products and services. Also, the presence of firms with foreign capital as bidders in public procurement practice signals to entrepreneurs the emergence of new opportunities to upgrade their capabilities.

The survey provides evidence that the potential of the public entity (number of PP and number of value), type of organization (public health units more frequently apply a multi-criterial model of incorporating innovation in tender criteria than other agencies) and size of entity dealing with PP have an important influence on application of multi-criterial model of offer evaluation.

Table 7 considers possibly applying the life-cycle cost (LCC) as a criterion to award public procurement contracts. It is worth mentioning that the EU Directives provide appropriate guidance for unambiguous LCC calculations. Almost all characteristics of public entities suggested that the contracting authority should allow to establish the LCC offer. An exemption in this table is the variable "experience of public sector entity in PP”, which turned out to be a non-significant factor.

Table 7. Life-cycle cost (LCC) calculations as a criterion of offer evaluations and characteristics of procurers (V-Cramer's coefficient)

\begin{tabular}{|l|c|c|c|}
\hline \multicolumn{1}{|c|}{ Characteristics of procurers } & V-Cramer's coefficient & p-value & Statistical significance \\
\hline Number of persons dealing with PP & $\mathbf{0 . 4 6 2}$ & $\mathbf{0 . 0 1 7}$ & yes \\
\hline Experience of public sector entity in PP & - & - & no \\
\hline Type of public sector entity & $\mathbf{0 . 6 1 2}$ & $\mathbf{0 . 0 0 0}$ & yes \\
\hline Annual number of PP & $\mathbf{0 . 4 6 7}$ & $\mathbf{0 . 0 2 0}$ & yes \\
\hline Annual value of PP & $\mathbf{0 . 5 4 9}$ & $\mathbf{0 . 0 0 1}$ & yes \\
\hline Presence of firms with foreign capital among bidders & $\mathbf{0 . 4 9 8}$ & $\mathbf{0 . 0 0 2}$ & yes \\
\hline
\end{tabular}

Source: Author's own elaboration based on Starzyńska [2012, p. 186].

Table 8 presents results of investigation of public procurer's opinions about "possibly conducting a preliminary market dialogue" with experts to collect information and feedback about the existence, feasibility and costs of possible solutions.

Table 8. PP procedures encouraging practice of PPI and characteristics of procurers

(V-Cramer's coefficient)

\begin{tabular}{|l|c|c|c|c|c|c|}
\hline \multirow{2}{*}{ Characteristics of procurers } & \multicolumn{2}{|c|}{ V-Cramer's coefficient } & \multicolumn{2}{|c|}{-value } & \multicolumn{2}{|c|}{ Statistical significance } \\
\cline { 2 - 7 } & $\begin{array}{c}\text { Competi- } \\
\text { tive } \\
\text { dialogue }\end{array}$ & $\begin{array}{c}\text { Technical } \\
\text { dialogue }\end{array}$ & $\begin{array}{c}\text { Competi- } \\
\text { tive } \\
\text { dialogue }\end{array}$ & $\begin{array}{c}\text { Tech- } \\
\text { nical } \\
\text { dialogue }\end{array}$ & $\begin{array}{c}\text { Competi- } \\
\text { tive } \\
\text { dialogue }\end{array}$ & $\begin{array}{c}\text { Technical } \\
\text { dialogue }\end{array}$ \\
\hline Number of persons dealing with PP & $\mathbf{0 . 3 3 3}$ & - & $\mathbf{0 . 0 0 3}$ & - & yes & no \\
\hline Experience of public sector entity in PP & - & - & - & - & no & no \\
\hline Type of public sector entity & - & $\mathbf{0 . 4 4 1}$ & - & $\mathbf{0 . 0 0 0}$ & no & yes \\
\hline Annual number of PP & $\mathbf{0 . 3 2 0}$ & - & $\mathbf{0 . 0 1 0}$ & - & yes & no \\
\hline Annual value of PP & - & $\mathbf{0 . 2 7 3}$ & - & $\mathbf{0 . 0 7 0}$ & no & yes \\
\hline $\begin{array}{l}\text { Presence of firms with foreign capital } \\
\text { among bidders }\end{array}$ & - & - & - & - & no & no \\
\hline
\end{tabular}

Source: Author's own elaboration based on Starzyńska [2012, p. 187]. 
Competitive dialogue and technical dialogue have been conceived for the procurement of complex contracts and, in consequence, for the procurement of innovation as well. Some conclusions can be derived from Table 8:

- the bigger the number of annual PP, the more often procurers identified "competitive dialogue" as a suitable instrument to promote PPI; and

- in the case of "technical dialogue", there are some relationships between type of public sector entities and size of PP purchased by an agency in a year. This procedure is mainly seen as stimulating the demand for innovation by NHS public entities and by entities characterized by relatively high values of annual public procurement.

Table 9 shows factors identified by public procurers that may diminish risks connected with PPI. Special attention was paid to the public-private partnerships (PPP) concept, which has recently been considered in the area of research and innovation (R\&I). The public entities with relative higher numbers and values of PP see this instrument as the innovation potential and savings by risk sharing. Risk sharing in pre-commercial procurement was identified by agencies characterized by relatively higher numbers of employees dealing with PP.

Table 9. PPI risks diminishing and characteristics of procurers (V-Cramer's coefficient)

\begin{tabular}{|c|c|c|c|c|c|}
\hline \multirow{2}{*}{$\begin{array}{l}\text { characteristics } \\
\text { of procurers }\end{array}$} & $\begin{array}{l}\text { Risk sharing } \\
\text { in PPP }\end{array}$ & $\begin{array}{l}\text { Risk sharing in } \\
\text { pre-commercial } \\
\text { procurement }\end{array}$ & $\begin{array}{l}\text { Supplier } \\
\text { pre-paying }\end{array}$ & $\begin{array}{c}\text { Risk } \\
\text { transmission to } \\
\text { supplier }\end{array}$ & $\begin{array}{c}\text { Property and } \\
\text { copyright law } \\
\text { transfer to procurer }\end{array}$ \\
\hline & $\begin{array}{c}\text { V C } \\
\text { (p-value) }\end{array}$ & $\begin{array}{c}\text { V C } \\
\text { (p-value) }\end{array}$ & $\begin{array}{c}\text { V C } \\
\text { (p-value) }\end{array}$ & $\begin{array}{c}\text { V C } \\
\text { (p-value) }\end{array}$ & $\begin{array}{c}\text { V C } \\
\text { (p-value) }\end{array}$ \\
\hline $\begin{array}{l}\text { Number of persons } \\
\text { dealing with PP }\end{array}$ & - & $\begin{array}{c}0.463 \\
(0.025)^{*}\end{array}$ & - & $\begin{array}{c}0.327 \\
(0.025)^{*}\end{array}$ & - \\
\hline $\begin{array}{l}\text { Experience of public } \\
\text { sector entity in PP }\end{array}$ & - & - & - & $\begin{array}{c}0.333 \\
(0.095) \\
\end{array}$ & - \\
\hline $\begin{array}{l}\begin{array}{l}\text { Type of public sector } \\
\text { entity }\end{array} \\
\end{array}$ & - & - & - & - & $\begin{array}{c}0.290 \\
(0.084) \\
\end{array}$ \\
\hline Annual number of PP & $\begin{array}{c}0.243 \\
(0.010)^{* *}\end{array}$ & - & - & $\begin{array}{c}0.344 \\
(0.014)^{*}\end{array}$ & $\begin{array}{c}0.305 \\
(0.044)^{*}\end{array}$ \\
\hline Annual value of PP & $\begin{array}{c}0.208 \\
(0.066)\end{array}$ & - & - & $\begin{array}{c}0.354 \\
(0.009)^{* *}\end{array}$ & - \\
\hline
\end{tabular}

$*$ - statistical significance for $\mathrm{p}<0.05 ; * *$ - statistical significance for $\mathrm{p}<0.01$

Source: Author's own elaboration based on Starzyńska [2012, p. 189].

It was a little surprising that characteristics connected with the potential of public purchasers are statistically significant if the risk of procurers transmitted to suppliers is considered.

In the context of property and copyright law transfer to procurers, the type of public sector entity and its annual number of PP are factors that may make them effective procurement innovative tools. 


\section{Discussion and conclusions}

Public procurement is increasingly treated as an attractive and feasible instrument for the application of innovation policy. Experience in this field proves that in the formal sphere, there are no obstacles of PPI in Poland, but the number and value of such contracts are very low compared with other EU countries.

The survey results prove that there is a statistically significant relationship between some characteristics of public procurers and their ability to proceed with an innovative public procurement. Special attention should be paid to the experience, size and amount of PP purchased by agencies per year.

Strategies and decisions on PPI are rarely addressed and resolved at the management level in public authorities. If a higher degree of procurement of innovation is to be achieved, a fundamental change to the structure of incentives in procurement by public authorities will be necessary [VINNOVA, 2007, p. 29].

Conclusions coming from the survey may be useful for elaborating an appropriate strategy for creating conditions to encourage pro-innovative activities of public entities. Next steps of investigation will aim to construct a model of cooperation between suppliers and public procurers with the help of researchers and a model of interaction: the public sector-university-private sector.

\section{References}

Adam, F., Measuring National Innovation Performance: The Innovation Union Scoreboard Revisited, Springer, Heidelberg-New York-Dordrecht-London 2014.

Appelt, S., Galindo-Rueda, F. Measuring the Link between Public Procurement and Innovation, Working Party of National Experts on Science and Technology Indicators, OECD 2014.

Aschhoff, B.,Sofka, W., Innovation on Demand: Can Public Procurement Drive Market Success of Innovations?, "Research Policy" 2009, Vol. 38, 1235-1247.

European Commission, Pre-Commercial Procurement: Driving Innovation to Ensure Sustainable High Quality Public Services in Europe, SEC (2007) 1668.

Izsak, K., Elder, J., Trends and Challenges in Demand-Side Innovation Policies in Europe, thematic report, Brussels 2011.

Kattel, R., Cepilovs, A., Drechsler, W., Kalvet, T., Lember, V., Tõnurist, P., Can we measure public sector innovation? A literature review, Ragnar Nurkse School of Innovation and Governance, Tallinn, Estonia, 9 January 2013. Version 0.1, preliminary draft, to be presented at EGPA 2013 conference.

OECD. Demand-side Innovation Policies, OECD Publishing 2011, http://dx.doi.org/10.1787/9789264098886en [access: 08.12.2011].

Office of Public Procurement, Reports about Functioning of the Polish Public Procurement System in the Years 2010-2016, Warsaw.

Rolfstam, M., Measuring Effects of Public Procurement of Innovation, paper presented at the XIX IRSPM Conference, University of Birmingham, UK, 30 March - 1 April 2015, p. 10.

Rolfstam, M., Public procurement as an innovation policy tool: the role of institutions, Science and Public Policy, Oxford University Press, vol. 36(5), June 2009.

Rolfstam, M., Petersen, H., Public procurement of innovation policy: The case of Denmark, [in:] L. Veiko, K. Rainer, K. Tarmo, Public Procurement, Innovation and Policy, Springer, London 2014. 
Schumpeter, J., The Theory of Economic Development, Oxford University Press, New York 1934.

Starzyńska, W., Próba oceny rozwoju innowacyjności poprzez zamówienia publiczne - wyniki badań wśród zamawiajacych, [in:] W. Starzyńska, J. Wiktorowicz (red.), Zamówienia publiczne a innowacyjność przedsiębiorstw - stan obecny i perspektywy, Wydawnictwo UŁ, Łódź 2012.

Starzyńska, W., Wiktorowicz, J. (red.), Zamówienia publiczne a innowacyjność przedsiębiorstw - stan obecny i perspektywy, Wydawnictwo UŁ, Łódź 2012.

Trochim, M.K., Evaluation Policy and Evaluation practice, American Evaluation Association, no. 123, San Francisco 2009.

UNOPS, Procurement and innovation, Supplement to the 2013 Annual Statistical Report on United Nations Procurement 2014, pp. 23-26.

VINNOVA, Public Procurement as a Driver for Innovation and Change, VINNOVA Policy 2007.

\section{Zamówienia publiczne a innowacyjność gospodarki - perspektywa zamawiających}

Polska wystartowała z zamówieniami publicznymi wprowadzając w $1995 \mathrm{r}$. Ustawę o zamówieniach publicznych. Od tego czasu w tym ustawodawstwie pojawiło się wiele zmian mających na celu poprawienie funkcjonowania systemu zamówień publicznych oraz doprowadzenie do zgodności tego systemu z dyrektywami Unii Europejskiej.

W 2004 r. Polska, stając się członkiem UE, opublikowała ustawę Prawo zamówień publicznych, która po szeregu nowelizacji obowiązuje do chwili obecnej. W nowych dyrektywach unijnych, uwzględnionych również w polskim Prawie zamówień publicznych, akcent położono na uwarunkowania sprzyjające innowacyjności poprzez zamówienia publiczne.

Celem niniejszego artykułu jest próba oceny tych uwarunkowań prawnych w odniesieniu do innowacyjnych zamówień publicznych. Ponadto opisano rezultaty badania empirycznego, polegającego na przeprowadzeniu wywiadów ankietowych wśród podmiotów zamawiających w Polsce na temat oceny potencjalnego wpływu zamówień publicznych na poprawę innowacyjności ofert.

\section{The Public Procurement and Innovativeness of Economy. The Perspective of Buying Agencies in Poland}

Poland started with the European public procurement rules in 1995 through publishing the Law of Public Procurement. Since then, many changes in this law have taken place in order to facilitate the system and to be compatible with the EU public procurement directives.

The most important solution in this field is the Law of Public Procurement introduced in 2004 when Poland became a member of the EU. Since 2004, many amendments have been introduced. In the European Union there are many political statements and reports demanding a system of public procurement mobilisation for innovativeness improvement.

The aim of this paper is to present framework for procurement in Poland. Further, there has been presented the empirical study connected with the survey conducted on the sample of awarding entities. In the paper some results of the investigation are analysed in order to answer the following question: Which factors could have an impact on public procurement innovativeness? 